\title{
THE ROLE OF REMITTENCES IN THE EXPLANATION OF FELDSTEIN-HORIOKA PARADOX: EVIDENCE FROM TRANSITION ECONOMIES
}

\begin{abstract}
We measure the level of capital mobility following Feldstein and Horioka (1980) who assume that measuring the extent to which national saving and investment rates are correlated indicate the degree of financial integration into the world economy. While they surprisingly found the high positive correlation between saving and investment in developed OECD economies, subsequent empirical studies on the sample of less developed economies found smaller saving-investment correlation. Concentrating on the determinants of investments in the transition economies that could explain now conventional, puzzling Feldstein-Horioka results for transition economies, we were the first who consider remittances as possible explanation. The results of panel analysis seem to support the hypothesis of capital mobility among the economies in transition for the period 1995-2007. Highly significant effect of remittances on investment supports our argument that a significant portion of received remittances is directed toward investment in transition economies.
\end{abstract}

Key words:capital mobility, Feldstein-Horioka puzzle, remittances, transition economies

\section{INTRODUCTION}

There is a common opinion that world's financial market is highly integrated, especially with rapid development of the new communication technologies and easily accessible information. Integration of the financial market is likely to be followed by capital mobility. The level of capital mobility can be measured in different ways and in our analyses we focused on the measure proposed by Feldstein and Horioka (1980). They assume that measuring the extent to which national saving and investment rates are correlated indicate the degree of financial integration into the world economy. While empirical work on this topic is extensive, it is mainly related to developed countries and in very limited number of cases the research is based on the sample of transition economies. More recent studies take into consideration that, apart from the savings, the other variables, such as aid or trade, have impact on investment and augmented the original $\mathrm{FH}$ model for these variables. Considering that remittances are one of the most important financial flows into transition group of economies, we primarily want to investigate their impact on the domestic investment-saving relation.

The structure of the paper is as follow: the next section presents the review of the most prominent empirical literature about Feldstein-Horiokapuzzleand considers the econometric methods and the results obtained in the analyses, with special emphasis on the analyses for the less developed and transition countries. The same section also provides a criticalassessment of

\footnotetext{
${ }^{1}$ MSc, Senior assistant, Faculty of Economics, University of Sarajevo, TrgOslobodjenja 1, merima.balavac@efsa.unsa.ba
} 
the previous methods and the results and points to common weaknesses in original FeldsteinHorioka and the later analyses.The theoretical basis for the variables in our model is given in the third section. We further give more information about importance of our variable of interest, remittances, for transition economies. The choice of the model, estimation procedure and estimation results are presented in the fourth section. After the description of the data used, the econometric estimates are presented. The concluding comments are provided in the fifth section.

\section{LITERATURE REVIEW}

\subsection{Felstein-Horioka model of saving-investment relation: results andinterpretation}

When perfect capital mobility is present, it is generally assumed that flows of capital would be directed toward the location with the most productive investment. If this assumption holds, there should not be high correlation between domestic saving and domestic investment.Formalisation of saving-investment relation as an indication of capital mobility can be attached to work of Feldstein and Horioka(1980) (further FH). They assume that capital (im)mobility can be revealed by observing investment reaction on change in saving (measured by $\beta$ ) from simple cross-section regression(1), also referred as FH model in the literature:

$(\mathrm{I} / \mathrm{Y})_{\mathrm{i}}=\alpha+\beta(\mathrm{S} / \mathrm{Y})_{\mathrm{i}}+u_{i} \quad i=1,2,3, \ldots \mathrm{N}$

where $(I / Y)_{i}$ is gross national investment to GDP ratio and $(S / Y)_{i}$ is gross national savings to $G D P$ ratio, $\alpha$ is intercept, $\beta$ is saving retention coefficient and $u_{i}$ is the error term.

As developed countries are characterized by the absence of widespread capital controls, the dominance of easily available information and deregulated financial markets, FeldsteinHorioka hypothesized that $\beta$ (in literature referred as saving retention coefficient) should not be statistically different from zero for OECD countries. However, the estimated coefficient for developed countries was surprisingly high (0.89), which Feldstein and Horioka (1980) interpreted as a signal of low capital mobility among the countries in the sample. Since FH results do not comply with theoretical expectation, results are often referred as "FH or globalization puzzle" and according to Obstfeld and Rogoff's (2000) classification,it is one of the six key puzzles in international economics. Au contraire to the conventionally accepted view that the global financial market is significantly integrated, the FH results raise doubts on the existence of financial globalization.

Official restrictions on the export of capital, possible institutional rigidities, currency and political risk and uncertainty, international differences of taxation and the interaction of foreign and domestic taxation (Feldstein and Horioka, 1980; Isaksson, 2001) have been recognized as possible explanations for retention of domestic savings within domestic territory. FH results became a conventional wisdom and any rejection of the FH puzzle has being considered as an exception rather than empirical regularity.

\subsection{Weaknesses of Feldstein-Horioka results}

Most authors have accepted the close correlation between savings and investment rates as a robust empirical regularity but deny that it is evidence for less than perfect capital mobility.

Further academic discussions about the FH puzzle suggest that concept of capital mobility is not a clear-cut analytical issue and often argue about the problem of identification of true 
meaning of $\mathrm{FH}$ retention coefficient. It is pointed out that a high saving-investment correlation does not necessarily reflect less than perfect capital mobility and low capital market integration. Literature suggests thatthe integration of global capital markets is a necessary but not sufficient condition for a net capital in/out-flow and this depends on a whole range of exogenous factors suchas the presence of the non-tradable goods (Wong, 1990), current account targeting by government expenditure ( Bayoumi,1990), economic or population growth (Obstfeld, 1986), the dependency ratio (Herwartz and $\mathrm{Xu}, 2009$ ) and productivity shocks such as technological change (Obstfeld, 1986; Stockman and Tesar, 1995). The saving-investment relation could also be attributed to a "large country effect" i.e. an endogenous domestic interest rate defined through influences that large country has on world interest rate(Baxter \&Crucini, 1993; Dooley et al., 1987,Herwartz and Xu, 2009).Another group of factors, referred as the "policy reaction" argument, is attributed to government actions and rests on assumption that government targets the current account balance and varies its economic policies to offset private net capital flows (Tobin, 1983). All those factors are considered to simultaneously affect saving and investment and omitting them from analyses is likely to cause misspecification in the cross-section estimation of the FH model.

There is an argument in theory that the interest sensitivity of saving and the covariance between savings and the error terms are not zero. According to discussion in the literature, the other factors, besides savings, could produce a correlation between saving and investment. If they are omitted from the model, they would go in error term and results in non-zero covariance between savings and error term. It implies possible endogeneity of savings and simultaneity bias attached to estimates of the $\mathrm{FH}$ coefficient.The problem of potential endogeneity has been considered in various analyses with different researchers using range of instruments (example of instruments are the ratio of military expenses to GNP and the dependency ratio used by Feldstein and Horioka (1980) or past savingsusedby Kasuga(2004)). However, it has often been found that the use of instrumental variable estimation does not change empirical results qualitatively.

\subsection{Estimation results for the less developed countries (LDC)}

Most of the empirical results suggest that, when LDCs are included in the sample, the high positive correlation between saving and investment does not exist. Since transition countries, the group of countries that we are primarily interested in, is considered to be subgroup of LDCs, we dedicate more attention to empirical findings for LDCs. If we consider a lower saving-investment correlation to be an indication of greater capital mobility, the results for LDCs seems to be less plausible due to the longer persistence of tight financial constraints in LDCs compared to OECD countries. Different studies (Dooley et al., 1987; Wong, 1990; Issakson, 2001; Kasuga,2004; Payne and Kumazawa, 2006) have found support for several possible explanationsof the LDCs' results: heterogeneity of financial characteristics and factor endowment; the size of the non-traded sector; the low correlation of returns between developing countries' market and easier access to foreign capital (mainly in form of cheap government debt and foreign aid). The lower saving retention coefficient for LDCs relative to developed countries has also been attributed to the "country size" factor which implies that in relatively small developing countries the world interest rate is taken as given (Dooley et al., 1987). Thus low saving-investment correlation in LDC, in light of afore mentioned factors, does not inevitably infer high capital market integration, as capital flows are mainly result of official transactions, while private investors still face controls and obstacles (Vamvakidis and Wacziarg , 1998). The results for LDC should also be interpreted 
with caution as there are possible inaccuracies that could affect the results' validity. Although estimation for the developed countries is not without problem, fragile results are more likely to be observed for developing than developed countries. It is argued that the results for LDCs are downward biased, largely due to errors in data measurement. This error could arise as a result of neglecting the significant level of the "shadow" economy, capital inflows in form of aid and remittances and capital outflows in form of debt repayments. Biased estimation of the FH retention coefficient for LDC sample is likely to be caused by omitting such factorsfrom analyses.

Transition countries have not largely been covered in literature and empirical work on the savings-investment relationship in transition economies is rather limited.Payne and Mohammadi (2006) analyse original FH estimation and suggest that the findings on the relation between savings and investment in transition economies are similar to those for developing countries, suggesting a low coefficient on savings and hence fairly high capital mobility between countries.

\section{THEORETICAL FRAMEWORK FOR EMPIRICAL ANALYSIS}

\subsection{Theoretical justification for independent variable selection}

Two approaches for testing capital mobility arise in the literature: the first is the structural model that requires testing interest rate differentials on capital across countries and the second is Feldstein and Horioka's proposition which measures the extent to which national saving and investment rates are correlated in order to determine the degree of financial integration in the world economy. Referring back to previous discussion, we adopted the Feldstein and Horioka(1980) proposition and use model (1) as a starting point for our analyses. Feldstein and Horioka's (FH's) puzzling results and their interpretation have provoked a dynamic discussion in both the theoretical and empirical literature. Following this model, the central variables in our analysesare the gross savings-GDP ratio and the gross investment- GDP ratio. Feldstein and Horioka suggest two arguments why gross and not net saving flows between countries are appropriate to be used in analyses. Firstly, the gross measure would give more consistency because differences in accounting definitions of depreciation across countries that could invalidate the measurement of net saving, especially in the presence of high inflation. Secondly, the gross measure of fixed capital formation is appropriate to be used since it excludes the procyclical inventories component that may lead to spurious correlations with savings (Bayoumi, 1990; Sinha and Sinha, 2004).However, the relationship with net data has been estimated and similar, but slightly higher coefficient obtained, possibly reflecting errors in measuring depreciation (Feldstein and Horioka, 1980).

The FH model provides very little interpretation of the relationship over time, but lots of studies (Isaksson, 2001;Georgopoulos and Hejazi, 2005; Younas, 2007) augmented the traditional saving-investment modelwith a time dummy ( $\mathrm{T}$ ) interacted with saving rates. The interaction variableaims to capture the change in the savings rate over time period and serves to evaluate the effectiveness of policy and institutional changes aimed to improve capital mobility. Further variables to be included in our model are also in line with previous studies. Empirical evidence shows that among many measures of openness, the flow of trade (imports and exports) appears to have the most consistent relationship with investment, indicating positive relationship between investment and trade (a review of studies given in Ndikumana, 2000). 
Feldstein and Horioka(1980) argue that the estimates for developing countries need further investigation because of possible endogeneity. They rely on Bhagwati's (1978) discussion, that the additional flow of foreign capital (government aid or private capital) into LDCs may give a negative bias in the saving-investment correlation. The same proposition is made by the other authors such as Montiel (1994) and Vamvakidis and Wacziarg (1998), who argue that foreign aid might largely drive the empirical findings of correlations for developing countries. Montiel discussed two possibilities: when all aid is directed toward investment activities and when only part of foreign aid is used for investment and the rest is used for consumption. In the former case, foreign aid and domestic savings are independent variables and the coefficient of the variables will correctly capture the independent effect of variables on domestic investment. Hence, neglect of aid in the FHmodel would be the source of regression misspecification. If the later situation prevails and the aid affects not just investment, the saving retention coefficient will pick up some of the effect of aid on investment and the omission of the foreign aid from regression would bias estimation of the saving retention coefficient. ${ }^{2}$ Since foreign aid is significant part of investment financing in developing countries, the empirical investigations of SI relation on LDCs samples includethe level of foreign aid in the investigation of the saving-investment relation.

\subsection{Adding new variables in the FH model: input from transition economies}

Along with a foreign aid, remittances are an important source of financing in transition economies. They constitute an increasingly important mechanism for the transfer of resources to developing countries in general and transition in particular.With remittances, an economy can spend more than it produces, import more than it exports or invest more than it saves. However, there is danger that remittances could create an economic dependency that undermines prospect of development.Remittances might behave in a similar manner as aid and are expected to be positively correlated with official capital flows (Buch and Kuckulenz, 2004).A significant, though generally small, part of remittances does go into uses that can be classifieddirectly as investment. ${ }^{3}$ However, remittances can be transferred for investment purposes indirectly. Although those flows could be significant, usually are not officially recorded in the balance of payments.

On the same basis as the argument considered above for foreign aid, we extended $\mathrm{FH}$ model to include remittances. We also control for the fact that transition countries from the sample joined the EU during the observed period and include an EU dummy (EU) ${ }^{4}$ to capture possible differences in the level of domestic investment that those countries may have after they join EU. It is the first time in the theory and empirical investigation of the FH puzzle that remittances are included in analyses and our prime interest is to observe whether remittances are part of the explanation of the FH results for transition economies, which will be discussed further in the text

\footnotetext{
${ }^{2}$ In the former case the measured savings rate would decline and estimated savings retention coefficient would be downward biased as a measure of the independent effect of saving on investment. Hence, the omission of foreign aid in that case would weakens savings-investment correlation i.e. indicate more capital mobility than is actually present.

${ }^{3}$ Several studies found that remittances are transferred in different type of domestic investment such as investment in land or buildings (Alderman ,1996 and Adams ,1998 cited in Chami, 2008).

${ }^{4} \mathrm{We}$ assign value of one to EU dummy for the period of EU membership and zero otherwise. We also consider Croatia as EU member along with the later group of countries, because Croatia fulfill economic condition to join EU in the same year as Bulgaria and Romania.
} 


\subsubsection{Importance of remittances for transition economies}

Workers' remittances to developing countries have been steadily increasing in the past decades (see Figure 1). In the mid-1990s they overtook the total of private portfolio flows,thereby becoming the second most important source of foreign exchange for the developing countries and the second to foreign direct investment (FDI).

Figure 1. Workers' Remittances and other inflows to Developing Countries

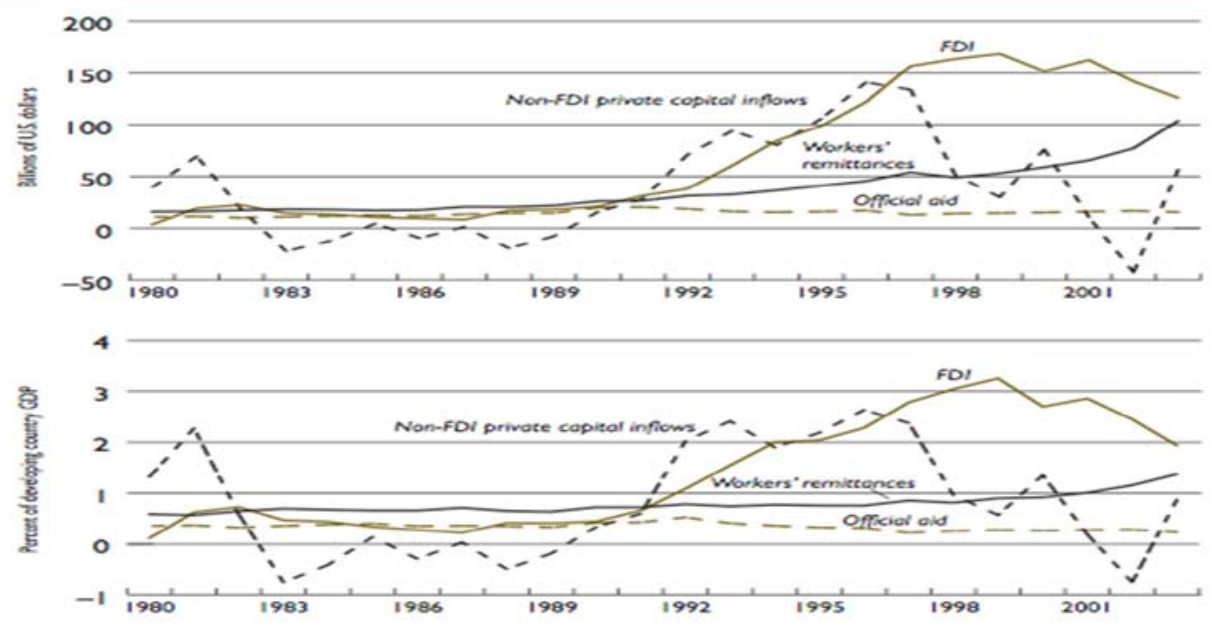

Source: Chami (2008)

The rising trend of world's remittance has continued in the first decade of the second millennium. From 2001 to 2007, remittance receipts measured as global receipts of "workers' remittances" and "compensation of employees" more than doubled to US\$336 billion (Table 1.).

Table 1. Compensation of Employees and Workers' Remittances, 2001 to 2007

\begin{tabular}{|c|c|c|c|c|c|c|c|}
\hline (In millions of US dollars) & 2001 & 2002 & 2003 & 2004 & 2005 & 2006 & 2007 \\
\hline \multicolumn{8}{|c|}{ Compensation of employees } \\
\hline Credit & 43,517 & 49,475 & 60,096 & 70,714 & 76,460 & 82,602 & 98,934 \\
\hline Debit & 51,030 & 57,312 & 67,926 & 76,463 & 84,883 & 95,144 & 113,975 \\
\hline Global discrepancy & 7,513 & 7,837 & 7,830 & 5,749 & 8,423 & 12,542 & 15,041 \\
\hline \multicolumn{8}{|l|}{ Workers' remittances } \\
\hline Credit & 81,168 & 93,410 & 112,693 & 126,007 & 153,009 & 180,715 & 237,396 \\
\hline Debit & 67,612 & 77,829 & 81,465 & 91,780 & 99,853 & 117,259 & 135,748 \\
\hline Global discrepancy & $-13,557$ & $-15,582$ & $-31,228$ & $-34,228$ & $-53,156$ & $-63,457$ & $-101,648$ \\
\hline \multicolumn{8}{|c|}{ Sum of compensation of employees and workers' remittances } \\
\hline Credit & 124,686 & 142,885 & 172,789 & 196,721 & 229,469 & 263,318 & 336,330 \\
\hline Debit & 118,642 & 135,141 & 149,391 & 168,242 & 184,736 & 212,403 & 249,72 \\
\hline Global discrepancy & $-6,043$ & $-7,745$ & $-23,398$ & $-28,479$ & $-44,733$ & $-50,915$ & $-86,608$ \\
\hline
\end{tabular}

Source: IMF’s Balance of Payments Statistics Yearbook 2008

According to Buch and Kuckulenz (2004), remittances provide a stable inflow of money to the receiving country, compared to other private capital inflows and official assistance (Figure 2). Chami(2008) presented the World Bank and IMF’s data on volatility of 
inflows for developing countries in period 1980-2003, which reveals that volatility of official aid was as three times as volatility of workers' remittances during observed period (Figure 2).

Figure 2. Volatility of inflows to developing countries , 1980-2003

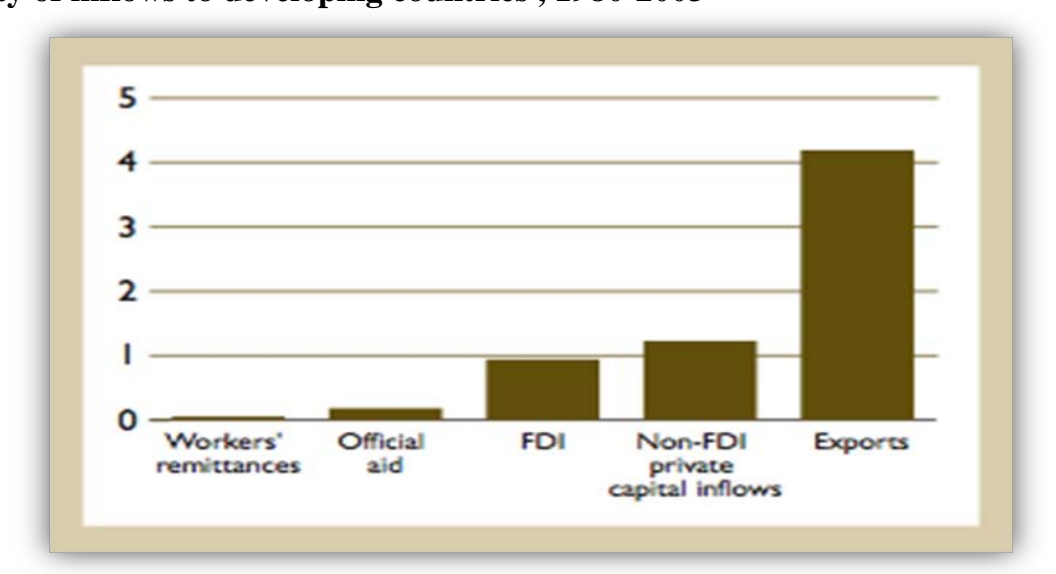

Sources: World Bank (2006) and IMF(2005)

Notes: Volatility is defined as the standard deviation of the detrended ratio of each variable to GDP

The same trend regarding importance of remittances is observed in our sample. On average, in the period 1995-2007, the remittances were far more important than aid in the most of the countries in our sample (Figure 3).

Figure 3. Average value of worker's remittances and aid expressed as \% of GDP for 1995-2007 for selected countries in our sample

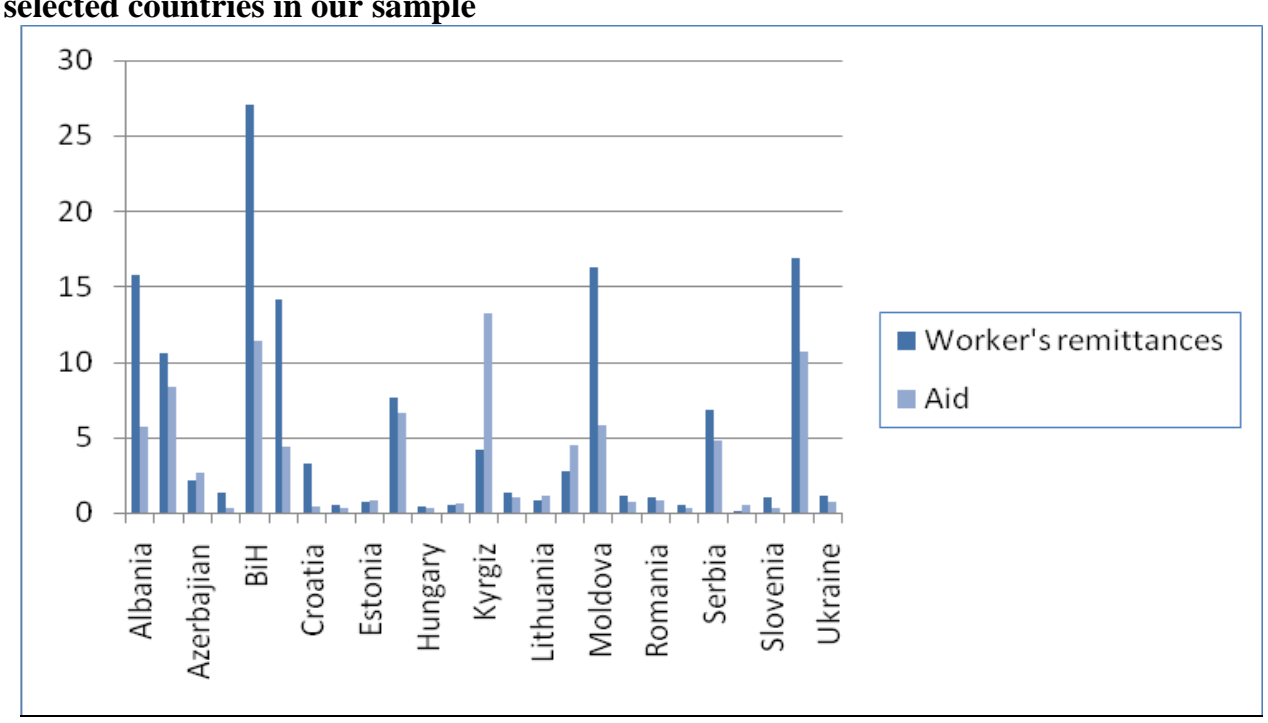

Source: World Bank Development Indicator (WDI) database (2008) and author’s calculation

There is considerable variation in the measure of remittances among the countries in our sample for observed period. For the entire study period from 1995 to 2007, the standard deviationof the average worker's remittances and employee's compensation across countries in sample ranged from 0.44 in Slovak Republic up to 12.72 in Tajikistan.

Overall, examination of the magnitude of the ratio of remittances to GDP in transition countries reveals their importance for economies. Although remittances have not been equally important for all countries, they help stabilizationof a number of transition economies and 
positively affect countries' macroeconomic performance in general and domestic investment in particular. Hence, inclusion of the remittances in our model is logical step in the analyses.

\section{MODEL ESTIMATION AND THE MAIN FINDINGS}

\subsection{The model}

Following previous discussion, model (2) is a model to be estimated: ${ }^{5}$

$$
\left(\frac{I}{Y}\right)=\alpha+\beta_{1}\left(\frac{S}{Y}\right)+\beta_{2} T+\beta_{3} T\left(\frac{S}{Y}\right)+\beta_{4}\left(\frac{E X+M}{Y}\right)+\beta_{5}\left(\frac{A}{Y}\right)+\beta_{6}\left(\frac{R}{Y}\right)+\beta_{7} E U+u
$$

where $I / Y$ is gross national investment to GDP ratio, $S / Y$ represent gross national savings to GDP ratio, $(E X+M) / Y$ is sum of export and import to GDP ratio, $A / Y$ is aid to GDP ratio, $R / Y$ is remittances to GDP ratio, $T$ is time dummy and $E U$ is $E U$ dummy accounted for the countries join EU.

It is a priori expected that the coefficient on the savings rate will be positive, but declining through time, which should be reflected in a negative coefficient on the interaction between the time dummy-savings rategiven the common view that capital mobility has been increasing. This is in line with a recent comprehensive survey of the vast empirical literature on FH puzzle by Apergis and Tsoumas (2009) who conclude that the majority of the empirical studies indicate a declining savings coefficient that opposes the original strong $\mathrm{FH}$ results but found that the correlation still exists in a weaker form. The ability of capital to move is greater in more open economies and hence coefficient on openness proxy is expected to be positive.Feldsten and Horioka (1980) also argue that it is likely that small economies which engage in substantial international trade have a much weaker link between domestic saving and domestic investment than the large ones, but they do not test for this proposition. Stockman and Tesar (1995) note that countries with greater ability to trade internationally have less strong relation between production and consumption and greater response of investment to change in rate of return. Foreign aid and similarly remittances are also expected to have a positive impact on investment rates. Membership in EU is expected to have positive effect on investment as well.

\subsection{Data description}

We use the a data set for 27 transition economies in Europe and Central Asia extracted from the World Bank Development Indicator (WDI) database(2008). Variables Y, S, I, EX and IM are provided directly in WDI. We used net official development assistance and official aid as a proxy for a variable aid in our model, while the series remittance is obtained from workers' remittance and employees' compensation. Since the availability and quality of economic data for transition economies from local sources is problematic, the consistency of the data in WDI was a prime reason for choosing this international database rather than national statistics to be the main data source. For 25 countriesanalysed, the longest period of consistent data with annual frequency is 1995-2007.Although the rest of the countries do not have data for the whole period in a consistent form, we usethese data as well yielding

\footnotetext{
${ }^{5}$ Empirical estimation of the model will be provided in the next section
} 
unbalanced panel, with limitedyears for the following countries: Czech Republic, Estonia, Kyrgiz and Latvia from 1995 to 2006 and Serbia from 1997 to 2007.

The capacities to save and invest (along with other factors such as the efficiency of investment) are broad indicators of the success of economic policies. By these measures, the majority of the EU members since 2004 (primarily Czech Republic, Estonia and Slovenia) and some of the Commonwealth of Independent States (CIS) countries such as Azerbaijan and Armenia, have been the most successful of the transition economies in our data set.Armeniarecorded remarkable success in this regard, boosting its savings/GDP ratio from $19.8 \%$ in 1995 to $19.2 \%$ in 2007 and its investment/GDP ratio from only $16.2 \%$ in 1995 to $33.3 \%$ in 2007 , i.e. changes of 38.58 and 17.1 percentage points.

The data on savings and investment reflects the unstable conditions on the transition markets and the external shocks affecting some countries, such as war in former Yugoslavia. It is expected and often confirmed that investments are higher than saving rates for individual countries and it is likely that this could be due to foreign aid or remittances (McKinley, 2004). Investment is higher than the saving rate on average for most countries (20 countries out of 25) in our sample.One of the recipients of substantial foreign aid and remittances, Bosnia and Herzegovina $(\mathrm{B} \& \mathrm{H})$, the country with the most damaged economy after the war in former Yugoslavia, has far the highest negative rate of savings among countries in the sample, indicating that total spending is more than the total income. While the level of national income in $\mathrm{B} \& \mathrm{H}$ is moderate and highly vulnerable to external shocks, at the same time $\mathrm{B} \& \mathrm{H}$ has the highest ratio of foreign aid and remittances to GDP.

Figure 5. Average value of gross domestic saving and gross domestic investment to GDP ratio for 1995-2007 for selected countries

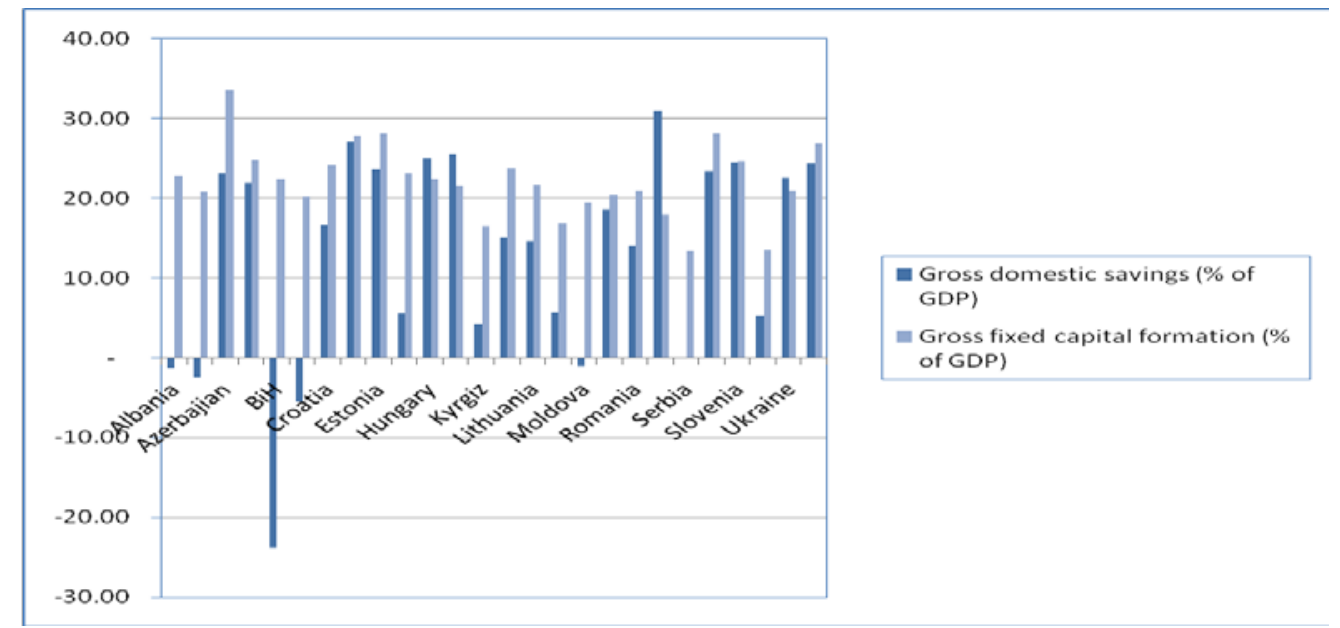

Source: World Bank Development Indicator (WDI) database (2008) and author’s calculation

Data on remittances, like other components of the balance of payments statements, arecompiled by relevant statistical authorities in member countries (typically the central bank ornational statistical office). In order to be consistent in data sources, we use WB categories,data on worker's remittancesand compensation of employees, as a proxy for remittances in our model. The WB measures only workers' remittances and compensation of employees, which comprise the current transfers by migrant workers and salaries earned by nonresident workers and are drawn mainly from IMF resources, complemented by WB staff estimates.Reinke (2007) explained that many weaknesses of existing data on remittances primarily arise as a result of the incomplete coverage of transactions, variation of reporting 
practice (such as the difference in the time of recording transactions) and the different interpretation of definition between countries. Since large numbers of remittances are not transferred through the formal banking system, especially in less developed countries such as transition countries, it is likely that the data are underestimated. Some transactions, such as financial assistance provided from migrants during their visits to their home country, are not sufficiently covered by customs data and they could be substantial where large migrant flows occur.Data could also be overestimated when imports and the amount temporary employees spend in their countries of employment are misidentified as a remittances. Balance of payment statistics show, under the compensation of employees, the remuneration paid by resident companies to nonresident employees and remuneration received by residents from nonresident employers. However, a part of these earnings is likely to be spent in the host economy and will therefore not accrue to the home economy as net income. Hence, at best the figures can only be regarded as estimates.

\subsection{Estimation of the model}

A priori, since a pooling model cannot control for unobserved country-specific heterogeneity, it seems appropriate to use a panel data estimation technique. Theory argues that since panel estimation techniques incorporate both time-series and cross-section dimensions of the data and increase the degrees of freedom of the estimator, collinearity among regressors is decreasedand coefficient estimates are more reliable in a panel context (Hsiao, 2003). The formal test explained further in Section 4.3.1 supports the view that panel estimation is more appropriate for our model.

\subsubsection{Static estimation}

We apply OLS and static panel estimation technique, fixed effects (FE) and random effects (RE) models. The model to be estimated is:

\section{OLS (Without Group Dummy Variables)}

$$
\left(\frac{I}{Y}\right)_{i t}=\alpha+\beta_{1}\left(\frac{S}{Y}\right)_{i t}+\beta_{2} T+\beta_{3} T\left(\frac{S}{Y}\right)_{i t}+\beta_{4}\left(\frac{E X+M}{Y}\right)_{i t}+\beta_{5}\left(\frac{A}{Y}\right)_{i t}+\beta_{6}\left(\frac{R}{Y}\right)_{i t}+\beta_{7} E U_{i t}+u_{i t}
$$

One-way FE model:

$$
\left(\frac{I}{Y}\right)_{i t}=\alpha_{i}+\beta_{1}\left(\frac{S}{Y}\right)_{i t}+\beta_{2} T+\beta_{3} T\left(\frac{S}{Y}\right)_{i t}+\beta_{4}\left(\frac{E X+M}{Y}\right)_{i t}+\beta_{5}\left(\frac{A}{Y}\right)_{i t}+\beta_{6}\left(\frac{R}{Y}\right)_{i t}+\beta_{7} E U_{i t}+u_{i t}
$$

One-way RE model :

$$
\left(\frac{I}{Y}\right)_{i t}=\alpha+\beta_{1}\left(\frac{S}{Y}\right)_{i t}+\beta_{2} T+\beta_{3} T\left(\frac{S}{Y}\right)_{i t}+\beta_{4}\left(\frac{E X+M}{Y}\right)_{i t}+\beta_{5}\left(\frac{A}{Y}\right)_{i t}+\beta_{6}\left(\frac{R}{Y}\right)_{i t}+\beta_{7} E U_{i t}+\left(\varepsilon_{i t}+u_{i}\right.
$$

It is expected to observe country-specific and time-invariant fixed factors and if those factors are correlated with domestic saving rates, the use of pooled data could provide a biased estimation of the retention coefficient. In the case of a fixed effect included in regression, any remaining unobserved heterogeneity that OLS does not control for will be captured within the panel framework (Younas, 2007). While FEmodels capture country-specific effects with $\alpha_{\mathrm{i}}$, that do not change over time, REincorporates heterogeneity among the countries by including 
a specific non-observable effect $\left(\varepsilon_{i t}\right)$ in the error term. Specification testing for effects versus OLS (LM and Likelihood ratio test) indicates that the effect models, fixed(FE) and random effects(RE) are preferable to OLS with probability of 0.000 of making type I error if we reject the $\mathrm{H}_{0}$ that group effect is constant with no variance between groups. The result of the Hausman test indicates that regressors are uncorrelated with random errorand that not just FE, but also RE, is consistent and could be used for estimation(Table 2.).

Table 2. LM, LR and Hausmantest for model (2)

\begin{tabular}{|c|c|c|c|c|}
\hline Specification tests & $\begin{array}{l}\text { Theoretical } \\
\text { distribution }\end{array}$ & Computed value & p-value & $H_{0}$ of the test \\
\hline LM & $x_{1}^{2}+f$ & 272.64 & 0.000 & The group variance is zero \\
\hline Likelihood & $x_{13 \mathrm{~d}}^{2} f$ & 18.12 & 0.000 & The group effects is constant \\
\hline Hausman & $x_{B}^{2}$ isf & 7.37 & 0.497 & $\begin{array}{l}\text { Random effects } \mathrm{u}_{\mathrm{i}} \text { and regressors are } \\
\text { uncorrelated }\end{array}$ \\
\hline
\end{tabular}

Since theHausmantests do not explicitly suggest which effects model, FE or RE, is preferred, our choice of FE model has several rationales. While RE properties are asymptotic, FE is preferred for small and moderate sized samples, which applies in our case. An emphasized disadvantage of the FE estimates, that inference is restrictedtothe set of crosssection units included in the estimation (Maddala, 2001), is not of concern as we are not interested in making inference for the countries outside our sample. Hence, our further inference relies on the results of the FE estimation.

\subsubsection{Estimation procedure and the main findings}

Firstly we estimate FE model with default standard errors. Although the results of the Wald test of joint significance of independent variables indicate that all independent variables, except the EU dummy and the saving-interaction term, have explanatory power with tstatistics showing individual significance at the conventional $1 \%$ and $5 \%$ level of significance, the result of the diagnostic tests raises doubts about coefficient validity. Serial correlation and heteroskedasticity of any kind would make standard errors biased and FE estimation inefficient and hence, we must consider estimation that takes those characteristics into account.

Hence, we estimate model with robust standard error in order to correct the standard errors for this heteroscedasticity. The revised estimates change the significance for aid, trade and trend (shaded area in Table 3), indicating the existence of heteroscedasticity within the cross-sectional units in our model. Heteroscedasticity in panel data could arise from unequal variance of error term across cross-sectional units, which is known as groupwiseheteroscedasticity(Baum, 2001). The highly significant result of test for groupwiseheteroscedasticityinfers that the variance of the error term differs across crosssection units given the p-value of 0.000 . The autocorrelation coefficient $(\rho)$ of 0.44 is larger than 0.3, Gujarati's(2003) suggested "rule of thumb" value above which there is an indication of the problem of serial autocorrelation. That there is such a problem is supported by the Wooldridge test of autocorrelation which gives a $0.000 \%$ probability of make Type I error if we reject the hypothesis of no autocorrelation. In macroeconomic relations such as investment-savings, it is likely that unobserved shock in current period will affect the relationship for at least the next few periods (Baltagi, 2008). Kezdi(2003) notes that practitioners have been ignored serial correlation consistent standard error estimators for panel models, although they were developed for FE models by Kiefer (1980), Bhargava et al. 
(1982), and Arellano (1987). He further argues that lack of use is likely to be attributed to possible finite-sample bias of the robust estimators. However, assuming no serial correlation when it is present results in a larger bias than the finite-sample bias of the robust estimators at any sample size.

Kezdi(2003), Wooldridge(2003, 2006) and Stock and Watson (2008) argues that the "clustered" estimator in fixed effect estimation accounts for within-panel correlation and is robust to heteroscedasticity. Nichols and Schaffer (2007) explain that FE, cluster-robust estimation firstly partial-out thefixed effects and then use the cluster-robust estimators to account for any remaining within-groupcorrelation. Studies indicate consistency and good finite sample properties of estimation. Possible problems of cluster robust errors are mainly related to the number of clusters needed for reliable inference. Monte-Carlo simulation provided by Kezdi (2003) shows that "cluster" estimates have less power in a smaller sample, but are not weaken with an increase in the time-span of the data. On the other handRogers (1993) infers that if clusters have equal sizeand the largest cluster is $5 \%$ or less of the sample, cluster-robust estimates with a moderate number of clusters, such as 20 , would suffer from a very small bias. Since we have moderately number of clusters (25), with very similar cluster size, we use the FE cluster-robust model, as a model for our further inference, but we report the estimated coefficient of all techniques utilized to indicate changes in standard errors and hence in the significance of variables (Table 3.).

Table 3. Comparison of p-values estimated by robust and non-robust one-way FE model

\begin{tabular}{|c|c|c|c|c|c|c|}
\hline \multicolumn{7}{|c|}{ Dependent variable: INVEST } \\
\hline \multirow{2}{*}{$\begin{array}{c}\text { Independent } \\
\text { variables }\end{array}$} & \multicolumn{2}{|c|}{ Non-robust one-way RE } & \multirow{2}{*}{\multicolumn{2}{|c|}{$\frac{\text { Robust one-way FE }}{\text { CoefficentP-value }}$}} & \multicolumn{2}{|c|}{ Cluster robust one-way FE } \\
\hline & Coefficent & P-value & & & Coefficent & P-value \\
\hline CONSTANT*** & 11.732 & 0.000 & 11.732 & 0.000 & 11.732 & 0.008 \\
\hline SAVINGS** & 0.201 & 0.000 & 0.201 & 0.000 & 0.213 & 0.000 \\
\hline TRADE* & 0.063 & 0.003 & 0.063 & 0.169 & 0.063 & 0.169 \\
\hline TREND** & 0.226 & 0.056 & 0.226 & 0.090 & 0.226 & 0.158 \\
\hline SAVTREND** & -0.006 & 0.120 & -0.006 & 0.274 & -0.006 & 0.380 \\
\hline EU & -1.046 & 0.120 & -1.046 & 0.244 & -1.046 & 0.332 \\
\hline AID & -0.202 & 0.044 & -0.202 & 0.068 & -0.202 & 0.134 \\
\hline WBREMIT & 0.317 & 0.000 & 0.317 & 0.001 & 0.317 & 0.001 \\
\hline
\end{tabular}

Goodness-of-fit in panel models is uncommon and is not appropriate to use as criteria for the choice between estimators (Verbeek, 2008). The estimate of autocorrelation coefficient (0.54) suggests that slightly more than a half variation in investment is related to intercountry differences in investment rates. The $\mathrm{F}$ test following the regression indicates that there are significant individual (country level) effects, implying that pooled OLS would be inappropriate.The correlation matrix (Table 4.) does not indicate with problems of highly correlated regressorsas the correlation coefficients on the variables are not higher than tolerance value of 0.8 . 
Table 4.Correlation matrix of coefficients of the model

\begin{tabular}{|l|l|l|l|l|l|l|l|l|}
\hline $\mathrm{e}(\mathrm{V})$ & savings & trend & savtrend & aid & wbremit & trade & eu & _cons \\
\hline savings & 1.0000 & & & & & & & \\
\hline trend & 0.1421 & 1.0000 & & & & & & \\
\hline savtrend & -0.2019 & -0.7102 & 1.0000 & & & & & \\
\hline aid & 0.4904 & -0.0040 & -0.0608 & 1.0000 & & & & \\
\hline wbremit & 0.2830 & -0.1477 & -0.2125 & 0.3326 & 1.0000 & & & \\
\hline trade & -0.2234 & 0.1514 & -0.5684 & -0.0192 & 0.1570 & 1.0000 & & \\
\hline eu & 0.0585 & -0.1456 & 0.2404 & 0.1962 & 0.0747 & -0.2840 & 1.0000 & \\
\hline cons & 0.0276 & -0.2763 & 0.6281 & -0.1712 & -0.2543 & -0.9623 & 0.2296 & 1.0000 \\
\hline
\end{tabular}

The independent variables joint have explanatory power in explaining investment, but not all are individually significant. Saving and remittances are highly significant at $1 \%$ level and have the expecteda priori positive effect on the investment rate (Table 3).The size of the retention coefficient is smaller compared to the original $\mathrm{FH}$ results and in line with previous findings for less developed countries. Our variable of interest, remittances, has highly significant impact on investment in all models, which supports our argument that a significant portion of received remittances is directed toward investment in transition economies. All the other variables, aid, trade, trend, savtrendand the EU dummy, are insignificant.The negative sign of savings-trend interaction term indicate increasing capital mobility over time, which was also confirmed in previous studies. An EU dummy has not been introduced in previous literature, as since the EU members are more developed, it was expected that the membership in EU would bring more investment. The actual estimation has the opposite sing but is insignificant.

\section{CONCLUSION}

The Feldstein-Horioka puzzling results that indicate immobility of capital in developed OECD economies has not been confirmed in the majority of studies for less developed countries. Our investigation was primarily concentrated on the determinants of investments in the transition economies that could explain now conventional, puzzling Feldstein-Horioka results for transition economies. More recent studies recognized aid to be a factor and included it as an independent variable in the model. Observing the categories of the balance of payment in transition economies, remittances are a more important financial flow than aid. Hence, on the same basis as aid, we also included remittances in the model and our prime goal was to investigate its impact on investment and capital mobility in general.

Following the literature, we investigate our hypothesis by applying static panel estimation technique. Specification tests for the static panel models and the characteristics of our variables indicate fixed effect model to be preferred. However, the results of investigation for autocorrelation and heteroscedasticity indicate the problems and give rise doubts to the validity of the results. Following Kezdi(2003), Wooldridge (2006) and Stock and Watson's 
(2008) proposition that fixed effect estimation with "cluster" standard errors is robust for these problems, we reported t-test based on these standard errors. We find a highly significant, positive effect of domestic savings and remittances on domestic investment.

The results seem to support the hypothesis of capital mobility among the economies in transition for the period 1995-2007. The evidence of high capital mobility among the countries in our sample (indicated by smaller absolute value of the savings coefficientcompared to the original FH results) seems to be consistent with the previous empirical findings for less developed countries. Including remittances in the model, gives an insignificant aid coefficient and a highly significant effect of remittances on investment, which supports our argument that a significant portion of received remittances is directed toward investment in transition economies.

Undoubtedly more research is necessary to examine level of capital mobility and its determinants for transition economies. We conducted our analyses using the best possible data on remittances available at this moment, but we acknowledge that there are some doubts on its quality.Due to acknowledge drawbacks in data on remittances, international organisations, such as IMF, have agreed on revision of the data. Hence, in the near future, it would be possible to obtain more quality analyses with the new, revised data. Generally for transition economies, the limited possible cross section and a short time span of data gives a relatively small sample and revision of the data and greater coverage of countries could result in better estimates in the future.Short span of data in transition economies limits application of time-series methods. However, time-series estimation seems to be appropriate in the context of the model estimated as macroeconomic variables, such as savings and investment, are usually random walk-like variables. Hence, estimation method, such as group mean panel dynamic OLS (DOLS) suggested by Pedroni (2001), seems to provide more robust results and it should be included in a future research, when more data for transition will be available.

\section{REFERENCES}

Arellano, M.,(1987), “Computing Robust Standard Errors for Within-Groups Estimators”, Oxford Bulletin of Economics and Statistics, 49(4): 431-34

Apergis, N. and Tsoumas, C., (2009), “A survey on the Feldstein-Horioka puzzle: what has been done and where we stand”, Research in Economics, 63(2): 64-76.

Bhagwati, J,N., (1978), Anatomy and Consequences of Exchange Control System, (Cambridge: NBER Books).

Baltagi, B.,(2008),Econometric Analyses of Panel Data, 4th Edition,(NY: John Wiley\&Sons)

Baum, F. C., (2001),An introduction to modern econometrics using Stata.(Texas: A Stata

Press Publication).

Baxter, M. and Crucini, M. J., (1993),” Explaining Saving/Investment Correlations”, American Economic Review, 83:416-436.

Bayoumi, T., (1990),“Savings-Investment Correlations: Immobile Capital, Government

Policy or Endogenous Behavior?”,IMF Staff Papers. 27, p. 360-387.

Buch, C.M. and Kuckulenz, A.,(2004),"Worker Remittances and Capital Flows to

Developing Countries”, Centre for European economic research, Discussion Paper No. 04-31.

Chami et al., (2008),“Macroeconomic Consequences of Remittances”, IMF Occasional paper259.

Dooley et al., (1987), “International Capital Mobility in Developing Countries Vs. Industrial 
Countries: What Do the Savings-Investment Correlations Tell Us”, IMF Staff Papers 34, p.503-529.

Feldstein, M.S., and HoriokaC.Y.,(1980),” Domestic Saving and International Capital Flows”, Economic Journal, 90:314-329.

Feldstein, M., (1983), "Domestic Saving and International Capital Movements in the Lon

Run and the Short Run”, European Economic Review, 21:129-151.

Georgopoulos, G. and Hejazi, W., (2005), “Feldstein-Horioka meets a time trend”, Economics Letters, 86:353-357.

Gujarati, D., (2004),Basic Econometrics,(New York:McGraw-Hill Companies Inc.). Herwartz,H and Xu, F. ,(2009),“A functional coefficient model view of the FeldsteinHorioka Puzzle”,Journal of International Money and Finance, 30: 1-18.

Isaksson, A., (2001),” Financial Liberalization, Foreign Aid, and Capital Mobility: Evidence from 90 Developing Countries”,Journal of International Financial Markets, Institutions, and Money, 11:309-338.

Kasuga, H. ,(2004)," Saving-investment correlations in developing countries”,Economics Letters, 83:371-6.

Kezdi, G., (2003),’RobustStandardErrorEstimationinFixed-EffectsPanel Models”,

Available at SSRN: http://ssrn.com/abstract=596988 (Accessed 13.07.2009).

Maddala,G.S. , (2001), Introduction to econometrics, $3^{\text {rd }}$ Edition, (NY: John Wiley\&Sons).

Montiel, P.J., (1994), "Capital Mobility in Developing Countries: Some Measurement Issues and Empirical Estimates”,The world bank economic review,8 (3):311-310.

Ndikumana, L., (2000), "Financial Determinants of Domestic Investment in Sub-Saharan

Africa: Evidence from Panel Data”,World Development, 28(2): 381- 400.

Nichols, A. and Schaffer, N.E., (2007),"Clustered standard errors in Stata",United Kingdom StataUsers'Group Meetings 2007 07, Stata Users Group.

Obstfeld, M., (1986),” How integrated are world capital markets? Some new tests”, National Bureau of Economic Research Working Paper: 2075.

Obstfeld, M. and Rogoff, K., (2000), “The Six Major Puzzles in International Macroeconomics: Is There a Common Cause?”,NBER Macroeconomics Annual, 15:340-390. Payne, J. and Kumazawa, R., (2006), ”Capital mobility and the Feldstein-Horioka puzzle:

Re- examination of less developed countries”, The Manchestor School, 74 (5): 610-616.

Payne, J. and Mohammedi, H., (2006), "Capital mobility and savings investment correlations:panel data evidence from transition economies”, Applied Economics Letters, 13:611-613.

edroni, P. (2001), "Purchasing Power Parity Tests in Cointegrated Panels," Review of

Economics and Statistics, 83:727-731

Reinke, J., (2007), "Remittances in the Balance of Payment Framework: Current problems and Forthcoming improvements", Paper presented at "Seminar on Remittance Statistics", Center of Excellence in Finance, Ljubljana.

Rogers, W. H., (1993), “Regression standard errors in clustered samples”,Stata Technical Bulletin,13:19-23.

Sinha, T., andSinha, D., (2004), “The Mother of All Puzzles Would Not Go Away”, EconomicLetters,82:259-267.

Stockman, A. and Tesar, L., (1995),” Tastes and Technology in a Two-Country Model of the 
Business Cycle: Explaining International Co-Movements”, American Economic Review, 85: $168-185$.

Stock, J.H. and Watson, M,W., (2008), "Heteroskedasticity-robust standard errors for fixed effectspanel data regression”,Econometrica, 76(1):155-174

Tobin, J., (1983), “ Comments on "Domestic Saving and International Capital Flows in the Long-Run and the Short-Run by M. Feldstein”,European Economic Review, 21:153-156.

Vamvakidis, A. andWacziarg, R., (1998),” Developing Countries and the Feldstien-Horioka

Puzzle”, IMF, Washington, DC. IMF Working Paper.

Verbeek, M., (2008), A guide to modern econometrics, $3^{\text {rd }}$ Edition,(NY: John Wiley\&Sons)

Wooldridge, J.M., (2006), “ Cluster-Sample Methods in Applied Econometrics: an extended

Analyses,” unpublished manuscript.

Wong, D.Y. ,(1990), "What Do Savings-Investment Relationships Tell Us about Capital

Mobility?” Journal of International Money and Financ,9:60-74.

\section{LOG NOVČANIH POŠILJAKA U OBJAŠNJENJU FELDSTEIN-HORIOKA PARADOKSA: DOKAZI IZ ZEMALJA U TRANZICIJI}

\section{SAŽETAK}

Razinu mobilnosti kapitala mjerimo slijedeći Feldsteinai Horioku (1980) koji kažu da mjerenje razmjera do kojeg su državne stope štednje i ulaganja korelirane, ukazuje na stupanj financijske integracije u svjetsku ekonomiju. I dok su neočekivano zaključili da postoji visok stupanj pozitivne korelacije između štednje i ulaganja u razvijenim OECD ekonomijama, kasnija empirijska istraživanja na uzorku manje razvijenih zemalja, pokazala su manju korelaciju štednje i ulaganja. Koncentrirajući se na odrednice ulaganja u tranzicijska gospodarstva koje bi mogle objasniti sada konvencionalne, zbunjujuć Feldstein-Horioka rezultate za tranzicijska gospodarstva, bili smo prvi koji su razmotrili novčane pošiljke kao moguće objašnjenje. Rezultati panelne analize idu u prilog hipotezi o mobilnosti kapitala u tranzicijskim gospodarstvima za period od 1995-2007. Vrlo značajan učinak novčanih pošiljaka na ulaganja podržava našu tvrdnju da je značajan udio primljenih novčanih pošiljaka usmjeren ka ulaganju u tranzicijska gospodarstva.

Ključne riječi: mobilnost kapitala, Feldstein-Horiokazagonetka, novčane pošiljke, tranzicijska gospodarstva 